\title{
Effect of organic selenium and zinc supplementation on fertility and hatchability of turkey eggs \\ ${ }^{1}$ Ogbu, N. N., ${ }^{2}$ Ogbu, ${ }^{*}$ C. C. and ${ }^{3}$ Ugwu, S. O. C.
}

${ }^{1}$ Department of Animal Breeding and Physiology, College of Animal Science and Animal Production, Michael Okpara University of Agriculture, Umudike, Abia State, Nigeria.

${ }^{2}$ Department of Animal Health and Production, College of Veterinary Medicine, Michael

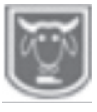

Abstract
Okpara University of Agriculture, Umudike, Abia State, Nigeria.

${ }^{3}$ Department of Animal Science,

University of Nigeria, Nsukka, Enugu State, Nigeria.

"corresponding author email: coschi07@yahoo.com

The study was carried out to evaluate the effects of organic selenium (Se-yeast, 0.20mg Se) and zinc (as zinc oxide) on fertility and hatchability of indigenous turkey eggs. Eighteen toms and twenty seven hens aged eighteen weeks were used for the study. The toms were randomly assigned to nine experimental treatments with two birds per treatment: Omg Se + 0mg Zn/kg ( $T_{1}$ or control), $0.2 m g \operatorname{Se}\left(T_{2}\right), 0.3 m g S e\left(T_{3}\right), 110 m g \operatorname{Zn}\left(T_{4}\right), 120 m g Z n\left(T_{5}\right), 0.2 m g ~ S e+110 m g$ $\mathrm{Zn}\left(T_{6}\right), 0.3 \mathrm{mg} \mathrm{Se}+110 \mathrm{mg} \mathrm{Zn}\left(T_{7}\right), 0.2 \mathrm{mg} \mathrm{Se}+120 \mathrm{mg} \mathrm{Zn}\left(T_{8}\right), 0.3 \mathrm{mg} \mathrm{Se}+120 \mathrm{mg} \mathrm{Zn} / \mathrm{kg}\left(T_{9}\right) \mathrm{in}$ a completely randomized design. At 32 weeks of age, semen was collected twice a week from toms in each treatment and used to inseminate hens belonging to the treatment. A total of 100 eggs in four batches were incubated from each treatment group and these were used to evaluate fertility, hatchability, and embryonic mortality. Supplementation of the diet of turkey toms with $0.3 \mathrm{mg}$ Se or $120 \mathrm{mg} \mathrm{Zn} / \mathrm{kg}$ of feed produced sperm which gave higher percentage fertility and hatchability and lower embryonic death in inseminated turkey hens compared to the control and those supplemented with $0.20 \mathrm{mg}$ Se or $110 \mathrm{mg} \mathrm{Zn/kg}$. Also the combination of Se and Zn improved fertility, hatchability, and embryonic viability than sole Se or Zn supplementation. Overall, supplementation with $0.3 \mathrm{mg} \mathrm{Se}+110 \mathrm{mg} \mathrm{Zn}$ or $0.3 \mathrm{mg} \mathrm{Se}+120 \mathrm{mg}$ $\mathrm{Zn} / \mathrm{kg}$ was found best to improve fertility, hatchability and embryonic viability in inseminated turkey hens.

Keywords: Turkey, selenium, zinc, semen, egg, fertility, hatchability

\section{Introduction}

Turkey production is an aspect of the poultry industry especially in the developed world where it plays a significant role in the supply of animal protein. Indigenous turkey production has not fulfilled a similar role in the tropics due to poor egg production, low fertility and hatchability (Ozcelik et al., 2009). The fertility level in a flock depends on a number of factors which include the health and nutritional status of the breeders, egg and semen quality. Apart from genetic improvement, fertility and hatchability could be improved in indigenous turkeys through improved nutrition and management.

Trace mineral nutrition has been shown to impact growth and reproductive traits such as fertility and hatchability. Selenium is involved in the regulation of growth, development, spermatogenesis and embryonic viability (Papazyan et al., 2006; Attia et al., 2010). Avian spermatozoa contain high levels of polyunsaturated fatty acids (PUFAs) responsible for the specific spermatozoan membrane properties such as fluidity, and flexibility. This high content of PUFAs however, predisposes sperm cells to 
Effect of organic selenium and zinc supplementation on fertility and hatchability of turkey eggs

high lipid peroxidation such that the antioxidant defense system is a key element of maintaining semen quality (Papazyan et al., 2006). Selenium in the form of gluthathione peroxidase (Se-GSH-Px) and thioredoxin reductase is responsible for the detoxification of hydroperoxide $(\mathrm{LOOH})$ radicals released in the process of detoxification of lipid peroxides (Papazyan et al., 2006). Selenium supplementation therefore enhances the antioxidant defenses of chicken semen (Surai et al., 1998) and spermatozoa integrity. Christensen et al. (2005) reported that fertility and embryo survival are functions of good sperm quality and the ability of sperm to bind to the ovum, hydrolyze the perivitelline layer, and penetrate the layer to initiate physiological events leading to fertilization and embryo development. Zinc is essential for spermatogenesis, sperm maturation in the epididymis, ovulation in females, fertilization, and embryo development (Glogowski et al., 2004; Mahmood and AlDaraji, 2011). It is important for capacitation, acrosome reaction, and in the maintenance of low metabolic rate during storage in the male reproductive system. Zinc is involved in the regulation of sperm motility, protection of sperm against oxidative damage, regulation of sperm chromatin condensation, and inhibition of transcription. It maintains sperm motility and prevents premature proacrosin activation during oviductal storage (Glogowski et al., 2004). Siudzinska and Lukaszewicz (2008) reported lower spermatozoa abnormalities in zinc supplemented groups which led to higher fertility. Balch (2007) and Mahmood and Al-Daraji (2011) reported that $\mathrm{Zn}$ helps to protect the structure of DNA chromatin in the sperm nucleus which aids successful fertilization. The reproductive capacity of indigenous turkeys needs to be enhanced to maximize turkey breeding and production in Nigeria. In the present study, we evaluated the effects of dietary supplementation of selenium and zinc on the fertilizing capacity of local turkey semen and the hatchability of turkey eggs.

\section{Materials and methods}

Location of study and experimental design

The experiment was carried out at the Poultry Research Unit of the Department of Animal Science, University of Nigeria Nsukka. A total of 45 growing local turkeys consisting of 18 toms and 27 hens at 18 weeks of age were used for the study. The toms were randomly assigned to nine experimental treatments with two birds per treatment (Table 1). Two basal diets namely growers mash (19\% CP, 3003Kcal ME $/ \mathrm{kg})$, and layers mash $(17.6 \% \mathrm{CP}, 2900 \mathrm{Kcal}$ $\mathrm{ME} / \mathrm{kg}$ ) were compounded for the study (Table 2). Selenium (Se) and zinc ( $\mathrm{Zn}$ ) were incorporated in the experimental diet and fed to the toms while the hens were fed unsupplemented layers mash. Feed and water were supplied to the birds ad libitum. The study lasted for 12 weeks.

\section{Semen collection, insemination of hens} and hatching of eggs

Toms were trained for semen collection for two weeks. Semen was collected from toms belonging to each treatment twice a week starting from 30 weeks of age using the manual massage technique by Burrows and Quinn (1937). Three hens were assigned to each group of toms for artificial insemination and hens were inseminated after one month in lay. Insemination was done twice a week between 16.00 and $18.00 \mathrm{~h}$ using $0.025 \mathrm{~mL}$ of pooled fresh semen per dose. Eggs were collected daily after five days of initial insemination between 30-35, 40-45, 50-55, and 60-65 weeks of age. Collected eggs were stored at room temperature and incubated within 


\section{Ogbu, Ogbu and Ugwu}

seven days of collection. A total of 900 eggs (100/treatment, 25/batch) were set in the incubator for evaluation of fertility and hatchability. Fertile eggs were determined by candling at the $14^{\text {th }}$ day of incubation. Eggs that did not hatch were broken to confirm fertility status while late embryonic deaths were recorded as dead in shell. Fertility was calculated as a percentage of total eggs set while hatchability was calculated as percentage of total and fertile eggs that hatched into live poults.

Proximate composition of experimental diet and statistical analysis

The experimental diet (growers mash) were analyzed for proximate composition by the methods of AOAC (1999). Data collected was subjected to multivariate analysis of variance in completely randomized design using the General Linear Model of the Statistical Package for Social Sciences (SPSS, 2007). Significant means were separated using the Duncan's New Multiple Range Test in SPSS (Duncan, 1955).

\section{Results and discussion}

Table 1 contains the experimental groups while Table 2 presents the percentage and proximate composition of the experimental diet (growers mash).

Table 1: supplementation of selenium (se) and zinc $(\mathrm{Zn})$ in experimental diets for turkeys

\begin{tabular}{lll}
\hline \multicolumn{3}{c}{ Experimental group (T) } \\
\hline $0.0 \mathrm{mg} \mathrm{Se}+0.0 \mathrm{mg} \mathrm{Zn}\left(\mathrm{T}_{1}\right)$ & $0.0 \mathrm{mg} \mathrm{Se}+110.0 \mathrm{mg} \mathrm{Zn}\left(\mathrm{T}_{4}\right)$ & $0.3 \mathrm{mg} \mathrm{Se}+110.0 \mathrm{mg} \mathrm{Zn}\left(\mathrm{T}_{7}\right)$ \\
$0.2 \mathrm{mg} \mathrm{Se}+0.0 \mathrm{mg} \mathrm{Zn}\left(\mathrm{T}_{2}\right)$ & $0.0 \mathrm{mg} \mathrm{Se}+120.0 \mathrm{mg} \mathrm{Zn}\left(\mathrm{T}_{5}\right)$ & $0.2 \mathrm{mg} \mathrm{Se}+120.0 \mathrm{mg} \mathrm{Zn}\left(\mathrm{T}_{8}\right)$ \\
$0.3 \mathrm{mg} \mathrm{Se}+0.0 \mathrm{mg} \mathrm{Zn}\left(\mathrm{T}_{3}\right)$ & $0.2 \mathrm{mg} \mathrm{Se}+110.0 \mathrm{mg} \mathrm{Zn}\left(\mathrm{T}_{6}\right)$ & $0.3 \mathrm{mg} \mathrm{Se}+120.0 \mathrm{mg} \mathrm{Zn}\left(\mathrm{T}_{9}\right)$ \\
\hline
\end{tabular}

$\mathrm{T}_{1}$ : control; all supplementation is per $\mathrm{kg}$ basal diet.

Table 2: Percentage and proximate composition of experimental diets for turkeys

\begin{tabular}{lll}
\hline & Growers mash & Layers mash \\
\hline Maize & 49.00 & 48.00 \\
Wheat offal & 13.00 & 14.00 \\
Soybean cake & 8.00 & 14.00 \\
Palm kernel cake & 13.00 & 12.00 \\
Groundnut cake & 10.00 & 3.00 \\
Fish meal & 2.00 & 2.00 \\
Bone meal & 4.00 & 2.00 \\
Limestone & - & 4.00 \\
Methionine & 0.25 & 0.25 \\
Lysine & 0.25 & 0.25 \\
Vitamin premix & 0.25 & 0.25 \\
Common salt & 0.25 & 0.25 \\
Total & 100 & 100 \\
Calculated composition & & \\
Crude protein (\%) & 19.00 & 17.60 \\
Energy (kcal/kg) & 3003.00 & 2900.00 \\
Proximate composition & & \\
Crude protein (\%) & 17.90 & \\
CHO (\%) & 52.14 & \\
Fibre (\%) & 12.66 & \\
Fat (\%) & 4.64 & \\
Ash (\%) & 9.39 & \\
Moisture (\%) & 3.28 & \\
\hline
\end{tabular}

Hens inseminated with semen from toms fed supplemental Se had higher percent fertile eggs compared to the control (Table 3). 
Effect of organic selenium and zinc supplementation on fertility and hatchability of turkey eggs

Table 3: Effect of sole Se supplementation on fertility and hatchability traits of turkey eggs

\begin{tabular}{lllll}
\hline Variable & Control & $\mathbf{0 . 2 0} \mathbf{m g ~ S e}$ & $\mathbf{0 . 3 0} \mathbf{m g ~ S e}$ & SEM \\
\hline Fertility (\%) & $64.67^{\mathrm{c}}$ & $76.33^{\mathrm{b}}$ & $88.00^{\mathrm{a}}$ & 1.02 \\
Dead fertile egg (\%) & $17.92^{\mathrm{a}}$ & $10.51^{\mathrm{b}}$ & $9.12^{\mathrm{b}}$ & 1.13 \\
Dead set eggs (\%) & $11.67^{\mathrm{a}}$ & $8.00^{\mathrm{b}}$ & $8.00^{\mathrm{b}}$ & 0.94 \\
Hatched fertile eggs (\%) & $81.53^{\mathrm{b}}$ & $89.49^{\mathrm{a}}$ & $90.88^{\mathrm{a}}$ & 1.08 \\
Hatched set eggs (\%) & $52.67^{\mathrm{c}}$ & $68.33^{\mathrm{b}}$ & $80.00^{\mathrm{a}}$ & 0.95 \\
\hline
\end{tabular}

abc: means on the same row with different superscripts are significantly different $(\mathrm{p}<0.05)$.

Fertility was also dose related as eggs from hens belonging to toms fed $0.30 \mathrm{mg} \mathrm{Se} / \mathrm{kg}$ were more fertile than those from hens inseminated with semen from toms fed $0.20 \mathrm{mg} \mathrm{Se} / \mathrm{kg}$ ( 88.00 vs $76.33 \%$ ). The percentages of dead fertile eggs and dead eggs based on set eggs were not statistically different between doses of Se but were significantly $(\mathrm{p}<0.05)$ lower in the group fed supplemented diets compared to the control (10.51 and 9.12 vs $17.92 \%$ and 8.00 and 8.00 vs $11.67 \%$, respectively). Hatchability of fertile eggs did not differ statistically between the supplemented groups but was higher in these groups compared to the control. Hatchability of incubated eggs was highest for eggs fertilized by semen of toms fed diet supplemented with $0.30 \mathrm{mg} \mathrm{Se} / \mathrm{kg}$ followed by those of toms supplemented with $0.20 \mathrm{mg} \mathrm{Se} / \mathrm{kg}$ and lowest in those of the control group. The higher fertility, and hatchability values and lower percent dead eggs observed in eggs of hens inseminated with semen of toms belonging to the supplemented groups indicated that $\mathrm{Se}$ supplementation in the diet of the toms enhanced semen quality, fertility, hatchability and embryo viability and that the control diet was probably deficient in this trace mineral. Selenium is proven to participate in the regulation of major physiological functions in humans and animals including growth, development, spermatogenesis and embryonic viability (Papazyan et al., 2006; Attia et al., 2010). The beneficial effects of selenium on performance of poultry species have been widely reported. Avian spermatozoa contain high levels of polyunsaturated fatty acids (PUFAs) responsible for the specific membrane properties-fluidity, flexibility, semi-permeability, etc of sperm cells. This high content of PUFAs however, predisposes sperm cells to high lipid peroxidation such that the antioxidant defense system is a key element of maintaining semen quality (Papazyan et al., 2006). Selenium in the form of gluthathione peroxidase (Se-GSH-Px) and thioredoxin reductase is responsible for the detoxification of lipid hydroperoxide $(\mathrm{LOOH})$ produced by the reaction of vitamin $\mathrm{E}$ with peroxyl radicals released in the process of detoxification of lipid peroxides (Papazyan et al., 2006). Selenium supplementation therefore enhances the antioxidant defenses of chicken semen (Surai et al., 1998) hence enhancing spermatozoa integrity. Christensen et al. (2005) reported that fertility and embryo survival are functions of good sperm quality and the ability of sperm to bind to the ovum, hydrolyse the perivitelline layer, and penetrate the layer to initiate physiological events leading to fertilization and embryo development. Sperm quality therefore determines fertility and hence hatchability. Reduced embryo livability coincidental with declines in fertility has been reported previously (Christensen and Fairchild, 1999). Both the form and level of Se in the diet influence the effect of the mineral on reproductive 


\section{Ogbu, Ogbu and Ugwu}

parameters (Leeson et al., 2008; Attia et al., 2010; El-Slamony et al., 2015). Edens (2002) reported high percent normal spermatozoa in cockerels fed $0.48 \mathrm{mg} \mathrm{Se} / \mathrm{kg}$ compared to those fed $0.28 \mathrm{mg} \mathrm{Se} / \mathrm{kg}$. The form of Se (Se-yeast) employed in the present study has been reported to be more effectively metabolized and therefore has greater bioavailability than inorganic Se (Edens, 2002; Leeson et al., 2008; Attia et al., 2010) and this may have been partly responsible for the improvement in fertility, hatchability and embryo viability observed in the treated groups.

The effects of zinc supplementation of toms on fertility and hatchability of turkey eggs showed a dose related response in all the traits measured (Table 4). Dietary zinc supplementation enhanced fertility and hatchability and reduced embryonic mortality. Fertility and hatchability was highest in eggs of hens belonging to toms supplemented with $120 \mathrm{mg} \mathrm{Zn/kg}$ followed by those of toms fed $110 \mathrm{mg} \mathrm{Zn} / \mathrm{kg}$ but lowest in those of unsupplemented control diet. In addition, percent dead eggs was significantly $(p<0.05)$ highest in eggs of hens belonging to toms in the control group followed by those of toms fed $110 \mathrm{mg} \mathrm{Zn} / \mathrm{kg}$ and lowest in those of toms fed $120 \mathrm{mg}$ $\mathrm{Zn} / \mathrm{kg}$.

Table 4: Effect of zinc ( $\mathrm{Zn}$ ) supplementation on fertility and hatchability traits of turkey eggs

\begin{tabular}{lllll}
\hline Variable & Control & $\mathbf{1 1 0} \mathbf{m g ~ Z n}$ & $\mathbf{1 2 0} \mathbf{m g} \mathbf{Z n}$ & SEM \\
\hline Fertility (\%) & $64.67^{\mathrm{c}}$ & $69.00^{\mathrm{b}}$ & $84.67^{\mathrm{a}}$ & 1.02 \\
Dead fertile eggs (\%) & $17.92^{\mathrm{a}}$ & $11.89^{\mathrm{b}}$ & $4.68^{\mathrm{c}}$ & 1.13 \\
Dead set eggs (\%) & $11.67^{\mathrm{a}}$ & $8.33^{\mathrm{b}}$ & $4.00^{\mathrm{c}}$ & 0.94 \\
Hatched fertile eggs (\%) & $81.53^{\mathrm{c}}$ & $88.11^{\mathrm{b}}$ & $95.32^{\mathrm{a}}$ & 1.08 \\
Hatched set eggs (\%) & $52.67^{\mathrm{c}}$ & $60.67^{\mathrm{b}}$ & $80.67^{\mathrm{a}}$ & 0.95 \\
\hline
\end{tabular}

abc: means on the same row with different superscripts are significantly different $(\mathrm{p}<0.05)$.

These results indicated that the basal diet (control) was deficient in zinc and that zinc supplementation has enhancing effect on sperm viability and fertilizing ability which translated to higher egg fertility and hatchability. Zinc is essential for spermatogenesis, sperm maturation in the epididymis, ovulation in females, fertilization, and embryo development (Glogowski et al., 2004; Mahmood and AlDaraji, 2011). It is important for capacitation, acrosome reaction, and in the maintainance of low metabolic rate during storage in the male reproductive system. Zinc is involved in the regulation of sperm motility, protection of sperm against oxidative damage, regulation of sperm chromatin condensation, and inhibition of transcription. It maintains sperm motility and prevents premature proacrosin activation during oviductal storage (Glogowski et al., 2004). Siudzinska and Lukaszewicz (2008) reported lower spermatozoa abnormalities in zinc supplemented groups which led to higher fertilizing ability of the spermatozoa. Balch (2007) and Mahmood and Al-Daraji (2011) reported that $\mathrm{Zn}$ helps to protect the structure of DNA chromatin in the sperm nucleus which aids successful fertilization. The inclusion levels of zinc in the present study were within the range of levels reported to enhance sperm quality, fertility and hatchability in chickens and turkeys. Jankowski et al. (2001) and Glogowski et al. (2004) reported that inclusion level of $120 \mathrm{mg} \mathrm{ZnO} / \mathrm{kg}$ diet of turkeys resulted in the best fertilizing ability of semen, highest hatchability, and lowest early and late embryonic mortality. Glogowski et al. 


\section{Effect of organic selenium and zinc supplementation on fertility and hatchability of turkey eggs}

(2004) therefore recommended optimal zinc level in diets for optimal reproductive performance in turkey-toms as $150 \mathrm{mg} / \mathrm{kg}$ or a supplementation of $120 \mathrm{mg} / \mathrm{kg}$ diet.

Supplementation of toms with $0.30 \mathrm{mg}$ $\mathrm{Se} / \mathrm{kg}$ produced higher fertility of $88.00 \%$ as against the 84.67 and $69.00 \%$ by toms fed 120 and $110 \mathrm{mg} \mathrm{Zn} / \mathrm{kg}$, respectively while toms fed $0.2 \mathrm{mg} \mathrm{Se} / \mathrm{kg}$ produced semen that gave higher fertility than toms fed $110 \mathrm{mg}$ $\mathrm{Zn} / \mathrm{kg}(76.33$ vs $69.00 \%)$ but lower to that due to $120 \mathrm{mg} \mathrm{Zn} / \mathrm{kg}$ supplementation (76.33 vs $84.67 \%$ ) (Table 5).

Table 5: E ffects of sole sel enium (Se) and zinc supplementation on fertility and hatching parameters of turkey eggs

\begin{tabular}{llllll}
\hline Variable & $\mathbf{0 . 2 0} \mathbf{m g ~ S e}$ & $\mathbf{1 1 0 m g ~ Z n}$ & $\mathbf{0 . 3 0} \mathbf{m g ~ S e}$ & $\mathbf{1 2 0 m g ~ Z n}$ & SEM \\
\hline Fertility (\%) & $76.33^{\mathrm{c}}$ & $69.00^{\mathrm{d}}$ & $88.00^{\mathrm{a}}$ & $84.67^{\mathrm{b}}$ & 1.02 \\
Dead fertile egg (\%) & $10.51^{\mathrm{a}}$ & $11.89^{\mathrm{a}}$ & $9.12^{\mathrm{a}}$ & $4.68^{\mathrm{b}}$ & 1.13 \\
Dead egg (\%) & $8.00^{\mathrm{a}}$ & $8.33^{\mathrm{a}}$ & $8.00^{\mathrm{a}}$ & $4.00^{\mathrm{b}}$ & 0.94 \\
Hatched fertile eggs (\%) & $89.49^{\mathrm{c}}$ & $88.11^{\mathrm{c}}$ & $90.88^{\mathrm{b}}$ & $95.32^{\mathrm{a}}$ & 1.08 \\
Hatched set eggs (\%) & $68.33^{\mathrm{b}}$ & $60.67^{\mathrm{c}}$ & $80.00^{\mathrm{a}}$ & $80.67^{\mathrm{a}}$ & 0.95 \\
\hline
\end{tabular}

abc: means on the same row with different superscripts are significantly different $(\mathrm{p}<0.05)$.

Percent dead eggs was lowest in eggs from hens belonging to toms fed $120 \mathrm{mg} / \mathrm{kg}$ zinc compared to those of 0.30 and $0.20 \mathrm{mg}$ $\mathrm{Se} / \mathrm{kg}$. Hatchability of fertile eggs was highest in eggs of hens inseminated with semen from toms fed $120 \mathrm{mg} \mathrm{Zn} / \mathrm{kg}$ followed by those of $0.30 \mathrm{mg} \mathrm{Se} / \mathrm{kg}$ while this trait did not differ significantly between $0.20 \mathrm{mg} \mathrm{Se} / \mathrm{kg}$ and $110 \mathrm{mg} \mathrm{Zn} / \mathrm{kg}$. Hatchability of set eggs was the same for eggs of hens belonging to toms fed $0.30 \mathrm{mg}$ $\mathrm{Se} / \mathrm{kg}$ and $120 \mathrm{mg} \mathrm{Zn} / \mathrm{kg}$ but higher compared to those of $0.2 \mathrm{mgSe} / \mathrm{kg}$ and $110 \mathrm{mg} \mathrm{Zn} / \mathrm{kg}$ which differed significantly (68.33\% for $0.20 \mathrm{mg} \mathrm{Se} / \mathrm{kg}$ vs $60.67 \%$ for $110 \mathrm{mg} \mathrm{Zn} / \mathrm{kg}$ ). Thus at the lower level of supplementation $(0.20 \mathrm{mg} \mathrm{Se} / \mathrm{kg}$ and $110 \mathrm{mg}$ $\mathrm{Zn} / \mathrm{kg}$ ), Se had stronger effect on fertility than zinc oxide. This result could be attributed to an enhanced antioxidative effect of Se due to synergistic interaction with other dietary nutrients such as vitamin E reported to function in tandem with Se in the scavenging of reactive lipid hydroperoxides in semen thereby enhancing sperm viability and subsequently fertility and hatchability (Papazyan et al., 2006). Similar synergistic relationship between vitamin $\mathrm{E}$ and zinc has not been established. Stanley et al. (2012) found no difference in egg production between hens fed sole Se and zinc but fertility was lower in the zinc supplemented group compared to those fed Se which agrees with the findings of the present study. On the other hand, El-Slamony et al. (2015) found no significant difference in fertility and hatchability of eggs of hens fed sole Se or zinc. The lowest percent dead eggs observed at the highest dose of zinc compared to the groups fed Se could mean that this level of zinc supplementation was sufficient to meet the requirements of the birds for zinc and hence had stronger positive effect on sperm viability. The need of zinc for sperm include maintainance of membrane stability, slowing metabolic reaction during storage, and inactivation of the enzyme acrosome (Glogowski et al., 2001) thus limiting acrosome reaction during sperm storage in vivo. Zinc deficiency is associated with impaired spermatogenesis, embryo development and mortality (Durmus et al., 2004; Mahmood and Al-Daraji, 2011).

Eggs of hens inseminated with semen from toms fed $0.30 \mathrm{mg} \mathrm{Se}+120 \mathrm{mg} \mathrm{Zn} / \mathrm{kg}$ diet were more fertile than those of other 


\section{Ogbu, Ogbu and Ugwu}

treatments followed by those of toms fed $0.20 \mathrm{mg} \mathrm{Se}+120 \mathrm{mg} \mathrm{Zn,} \mathrm{0.30mg} \mathrm{Se} \mathrm{+}$ $110 \mathrm{mg} \mathrm{Zn}$ and $0.20 \mathrm{mg} \mathrm{Se}+110 \mathrm{mg} \mathrm{Zn/kg}$ but lowest in the control (93.33 vs 90.00 , 88.67 and 88.33 vs $64.67 \%$ ) (Table 6).

Table 6: Effects of combinations of selenium (Se) and zinc ( $\mathrm{Zn})$ on fertility and hatchability parameters of turkey eggs

\begin{tabular}{|c|c|c|c|c|c|c|}
\hline Variable & Control & $\begin{array}{l}0.20 \mathrm{mg} \mathrm{Se}+ \\
110 \mathrm{mg} \mathrm{ZnO}\end{array}$ & $\begin{array}{l}0.30 \mathrm{mg} \mathrm{Se}+ \\
110 \mathrm{mg} \mathrm{ZnO}\end{array}$ & $\begin{array}{l}0.20 \mathrm{mg} \mathrm{Se}+ \\
120 \mathrm{mg} \mathrm{ZnO}\end{array}$ & $\begin{array}{l}0.30 \mathrm{mg} \mathrm{Se}+ \\
120 \mathrm{mg} \mathrm{ZnO}\end{array}$ & SEM \\
\hline Fertility (\%) & $64.67^{\mathrm{c}}$ & $88.33^{\mathrm{b}}$ & $88.67^{\mathrm{b}}$ & $90.00^{\mathrm{b}}$ & $93.33^{\mathrm{a}}$ & 1.02 \\
\hline Dead fertile eggs (\%) & $17.92^{\mathrm{a}}$ & $9.07^{\mathrm{b}}$ & $4.74^{\mathrm{c}}$ & $8.90^{\mathrm{b}}$ & $4.55^{\mathrm{c}}$ & 1.13 \\
\hline Dead set eggs (\%) & $11.67^{\mathrm{a}}$ & $8.00^{\mathrm{b}}$ & $4.33^{c}$ & $8.00^{\mathrm{b}}$ & $4.33^{\mathrm{c}}$ & 0.94 \\
\hline Hatched fertile eggs (\%) & $81.53^{\mathrm{a}}$ & $90.94^{\mathrm{b}}$ & $95.26^{\mathrm{a}}$ & $91.10^{\mathrm{b}}$ & $95.45^{\mathrm{a}}$ & 1.08 \\
\hline Hatched set eggs (\%) & $52.67^{\mathrm{d}}$ & $80.33^{c}$ & $84.33^{b}$ & $82.00^{\mathrm{bc}}$ & $89.00^{\mathrm{a}}$ & 0.95 \\
\hline
\end{tabular}

abc: means on the same row with different superscripts are significantly different $(\mathrm{p}<0.05)$.

Percent dead eggs were highest in eggs laid by hens mated to toms in the control group and lowest in eggs of hens mated to toms fed $0.30 \mathrm{mg} \mathrm{Se}+110 \mathrm{mg} \mathrm{Zn} / \mathrm{kg}$ and $0.30 \mathrm{mg}$ $\mathrm{Se}+120 \mathrm{mg} \mathrm{Zn} / \mathrm{kg}$. Hatchability of fertile eggs was similar between $0.30 \mathrm{mg} \mathrm{Se}+$ $110 \mathrm{mg} \mathrm{Zn} / \mathrm{kg}$ and $0.30 \mathrm{mg} \mathrm{Se}+120 \mathrm{mg}$ $\mathrm{Zn} / \mathrm{kg}$ groups (95.45 and $95.26 \%$, respectively) but these were higher compared to those of $0.20 \mathrm{mg} \mathrm{Se}+110 \mathrm{mg}$ $\mathrm{Zn} / \mathrm{kg}$ and $0.20 \mathrm{mg} \mathrm{Se}+120 \mathrm{mg} \mathrm{Zn/kg}$ groups which were also similar but higher than that of the control (91.10 and 90.94\% vs $81.53 \%$, respectively). Hatchability of set eggs was highest in eggs of hens mated to toms fed $0.30 \mathrm{mg} \mathrm{Se}+120 \mathrm{mg} \mathrm{Zn} / \mathrm{kg}$ and lowest in those of the control (52.67\%). The highest fertility and hatchability values and lowest embryo mortality observed in eggs of turkey-hens inseminated with semen of toms fed $0.30 \mathrm{mgSe}+120 \mathrm{mgZn} / \mathrm{kg}$ indicate that this level of combination of Se and $\mathrm{Zn}$ benefited fertility, hatchability and embryo viability more than the other treatments and the control diet. Reports on the effect of Se + $\mathrm{Zn}$ on fertilizing ability of semen are scarce; however the combined effect of Se and zinc on reproductive performance of hens has been reported by a number of studies. For instance Stanley et al. (2012) reported nonsignificant $6 \%$ and $3 \%$ increase in egg production and hatchability of fertile eggs, respectively and significantly lower early and late embryonic mortality in eggs of hens fed $\mathrm{Se}+\mathrm{Zn}$ compared to the control. In a study that compared the effects of dietary seleno-methionine and zinc glycine on hormonal, productive, reproductive, and physiological parameters of laying hens, ElSlamony et al. (2015) found the highest fertility and hatchability in eggs of hens fed a combination of the highest doses of seleno-metionine and zinc glycine (0.30mgSel-plex + 125mgZn-glycine). The effects of sole $\mathrm{Se}$ and $\mathrm{Se}+\mathrm{Zn}$ supplementation on fertility and hatchability are shown in Table 7.

Table 7: Compa rative effect of sole $\mathrm{Se}$ and $\mathrm{Se}+\mathrm{Zn}$ on fertility and hatching parameters of turkey eggs

\begin{tabular}{|c|c|c|c|c|c|c|c|}
\hline Variable & $\begin{array}{l}0.20 \mathrm{mg} \\
\text { Se }\end{array}$ & $\begin{array}{l}0.20 \mathrm{mg} \mathrm{Se} \\
+110 \mathrm{mg} \mathrm{Zn}\end{array}$ & $\begin{array}{l}0.20 \mathrm{mg} \mathrm{Se} \\
+120 \mathrm{mg} \mathrm{Zn}\end{array}$ & $\begin{array}{l}0.30 \mathrm{mg} \\
\text { Se }\end{array}$ & $\begin{array}{l}0.30 \mathrm{mg} \mathrm{Se} \\
+110 \mathrm{mg} \mathrm{Zn}\end{array}$ & $\begin{array}{l}0.30 \mathrm{mg} \mathrm{Se} \\
+120 \mathrm{mg} \mathrm{Zn}\end{array}$ & SEM \\
\hline Fertility (\%) & $76.33^{\mathrm{c}}$ & $88.33^{\mathrm{b}}$ & $90.00^{\mathrm{a}}$ & $88.00^{\mathrm{b}}$ & $88.67^{\mathrm{b}}$ & $93.33^{\mathrm{a}}$ & 1.02 \\
\hline Dead fertile egg $(\%)$ & 10.51 & 9.07 & 8.90 & $9.12^{\mathrm{a}}$ & $4.74^{\mathrm{b}}$ & $4.55^{\mathrm{b}}$ & 1.13 \\
\hline Dead set egg $(\%)$ & 8.00 & 8.00 & 8.00 & $8.00^{\mathrm{a}}$ & $4.33^{\mathrm{b}}$ & $4.33^{\mathrm{b}}$ & 0.94 \\
\hline Hatched fertile eggs $(\%)$ & 89.49 & 90.93 & 91.10 & $90.88^{b}$ & $95.26^{\mathrm{a}}$ & $95.45^{\mathrm{a}}$ & 1.08 \\
\hline Hatched set eggs $(\%)$ & $68.33^{\mathrm{b}}$ & $80.33^{\mathrm{a}}$ & $82.00^{\mathrm{a}}$ & $80.00^{\mathrm{c}}$ & $84.33^{\mathrm{b}}$ & $89.00^{\mathrm{a}}$ & 0.95 \\
\hline
\end{tabular}

abc: means on the same row with different superscripts are significantly different $(\mathrm{p}<0.05)$. 


\section{Effect of organic selenium and zinc supplementation on fertility and hatchability of turkey eggs}

The table showed that supplementation with $0.20 \mathrm{mgSe}+120 \mathrm{mgZn} / \mathrm{kg}$ gave the highest fertility value of $90.00 \%$ followed by supplementation with $0.20 \mathrm{mgSe}+$ $110 \mathrm{mgZn} / \mathrm{kg}(88.33 \%)$ and these were significantly higher than the value observed in the group fed sole $0.20 \mathrm{mgSe} / \mathrm{kg}$. Hatchability of fertile eggs and embryo mortality did not differ statistically between these groups but hatchability of set eggs was least in the group fed sole $\mathrm{Se}$ at $0.20 \mathrm{mg} / \mathrm{kg}$. For toms fed $0.30 \mathrm{mgSe} / \mathrm{kg}$, fertility and hatchability of set eggs were highest in eggs of hens mated to toms fed $0.30 \mathrm{mgSe}+120 \mathrm{mgZn} / \mathrm{kg}$ followed by those of $0.30 \mathrm{mgSe}+110 \mathrm{mgZn} / \mathrm{kg}$. These groups also had the least embryonic mortality. Hens mated to toms fed $0.30 \mathrm{mgSe}$ alone produced eggs with the least values of fertility, and hatchability and the highest values of percent dead eggs. Generally, for each level of Se supplementation, the combination of $\mathrm{Se}$ with zinc enhanced fertility and hatchability and decreased embryonic death more than sole Se supplementation and these effects were more with the highest dose of zinc. These results are in disagreement with ElSlamony et al. (2015) who reported statistically similar values for fertility, and hatchability for sole selenium and combined Se and $\mathrm{Zn}$ supplementation in laying Golden Montazah chickens.

Semen of toms fed $110 \mathrm{mgZn} / \mathrm{kg}$ diet alone produced the least values of fertility, and hatchability and highest percent dead eggs (Table 8).

Table 8: Comparative effect of sole $\mathrm{Zn}$ and $\mathrm{Zn}+$ Se on fertility and hatching parameters of turkey eggs

\begin{tabular}{llllllll}
\hline Variable & $\mathbf{1 1 0 m g}$ & $\mathbf{0 . 2 0} \mathbf{m g ~ S e}$ & $\mathbf{0 . 3 0} \mathbf{m g ~ S e}$ & $\mathbf{1 2 0} \mathbf{m g}$ & $\mathbf{0 . 2 0} \mathbf{m g ~ S e}$ & $\mathbf{0 . 3 0 m g ~ S e}$ & SEM \\
& $\mathbf{Z n}$ & $+\mathbf{1 1 0} \mathbf{m g ~ Z n}$ & $+\mathbf{1 1 0} \mathbf{m g ~ Z n}$ & $\mathbf{Z n}$ & $\mathbf{+ 1 2 0} \mathbf{m g ~ Z n}$ & $\mathbf{+ 1 2 0} \mathbf{m g ~ Z n}$ & \\
\hline Fertility (\%) & $69.00^{\mathrm{b}}$ & $88.33^{\mathrm{a}}$ & $88.67^{\mathrm{a}}$ & $84.67^{\mathrm{c}}$ & $90.00^{\mathrm{b}}$ & $93.33^{\mathrm{a}}$ & 1.02 \\
Dead fertile egg (\%) & $11.89^{\mathrm{a}}$ & $9.07^{\mathrm{a}}$ & $4.74^{\mathrm{b}}$ & $4.68^{\mathrm{b}}$ & $8.90^{\mathrm{a}}$ & $4.55^{\mathrm{b}}$ & 1.13 \\
Dead set eggs (\%) & $8.33^{\mathrm{a}}$ & $8.00^{\mathrm{a}}$ & $4.33^{\mathrm{b}}$ & $4.00^{\mathrm{b}}$ & $8.00^{\mathrm{a}}$ & $4.33^{\mathrm{b}}$ & 0.94 \\
Hatched fertile eggs (\%) & $88.11^{\mathrm{b}}$ & $90.93^{\mathrm{b}}$ & $95.26^{\mathrm{a}}$ & $95.32^{\mathrm{a}}$ & $91.10^{\mathrm{b}}$ & $95.45^{\mathrm{a}}$ & 1.08 \\
Hatched set eggs (\%) & $60.67^{\mathrm{c}}$ & $80.33^{\mathrm{b}}$ & $84.33^{\mathrm{a}}$ & $80.67^{\mathrm{b}}$ & $82.00^{\mathrm{b}}$ & $89.00^{\mathrm{a}}$ & 0.95 \\
\hline
\end{tabular}

abc: means on the same row with different superscripts are significantly different $(\mathrm{p}<0.05)$

A similar trend was observed in the groups fed $120 \mathrm{mg} / \mathrm{kg}$ zinc oxide. Toms fed $120 \mathrm{mgZn} / \mathrm{kg}$ diet alone produced semen with the least fertility and hatchability values compared to those fed a combination of zinc and selenium. Percent dead eggs was highest in the group fed $0.20 \mathrm{mg} \mathrm{Se}+$ $120 \mathrm{mg} \mathrm{Zn} / \mathrm{kg}$ compared to those fed $120 \mathrm{mgZn} / \mathrm{kg}$ sole and $120 \mathrm{mgZn}+0.30 \mathrm{mg}$ $\mathrm{Se} / \mathrm{kg}$ which were similar. The observed significantly improved fertility, hatchability and embryo viability on supplementation with combined selenium and zinc (Tables 7 and 8) could result from improved spermatozoa viability and fertilizing ability probably sequel to improved antioxidant properties of selenium and zinc resulting from the synergistic interaction between these elements (Jacob et al., 1999; Holger et al., 2004). Holger et al. (2004) reported that selenium generates binding sites for zinc in proteins in vivo and that zinc release from metallothioneins by selenium is a significant aspect of the therapeutic antioxidant action of selenium compounds. On the other hand zinc is reputed to potentiate the oxido-reductive potentials of selenium (Jacob et al., 1999). Ogbu et al. (2016) had reported improved semen quality and biochemical constituents in toms fed combinations of $\mathrm{Se}$ and zinc compared to those fed sole Se or zinc in diet.

\section{Conclusion}

Dietary supplementation with $\mathrm{Zn}$ and Se for 
toms improved the fertility and hatchability traits of turkey eggs. Also the combined effects of $\mathrm{Se}+\mathrm{Zn}$ were largely better than sole $\mathrm{Se}$ or $\mathrm{Zn}$ supplementation. Thus, combination of selenium and zinc can be used as an efficient tool for improving the reproductive potentials of turkeys.

\section{Reference}

Amen, M. H. M. and Al-Daraji, H. J. 2011. Effect of dietary supplementation owith different levels of zinc on sperm egg penetration and fertility traits of broiler breeder chicken. Pakistan Journal of Nutrition 10 (11): 10831088.

AOAC 1999. Official Methods of Analysis $16^{\text {th }}$ ed., Association of Official Analytical Chemists, Washington, D.C.

Attia, Y. A., Abdalah, A. A., Zeweil, H. S., Bovera, F., Tag EL-Din, A. A. and Araft, M. A. 2010. Effect of inorganic or organic selenium supplementation on productive performance, egg quality and some physiological traits of dual-purpose breeding hens. Czech. J. Anim. Sci. 55 (11): 505-519.

Balch, J. 2007. Vitamins for a low sperm count. Accessed from www. Buzzle. Com.

Burrows, W. H. and Quinn, J. P. 1937. The Collection of Spermatozoa from the domestic fowl and turkey. Poultry Sci. 16: 19-24.

Christensen, V. L. and Fairchild, B. D. 1999. Maternal and environmental influence on fertility and embryonic survival. Proc. Int. Congr. Bird Reprod., Tours, France. Pp 133-137.

Christensen, V. L., Fairchild, B. D., Ort, D. T. and Nestor, K. E. 2005. Dam and sire effects on sperm penetration of the perivitelline layer and resulting fecundity of different lines of turkeys. J. appl. Poult. Res. 14: 483-491.

Duncan, D. B. 1955. Multiple Range and Multiple F-tests. Biometrics 11: 142.

Durmus, I., Atasoglu, C., Mizrak, C., Ertas, S. and Kaya, M. 2004. Effect of increasing zinc concentration in the diets of brown parent stock layers on various production and hatchability traits. Arch. Tierz., Dummerstorf 47 (5): 483-489.

Edens, F. W. 2002. Practical application for selenomethionine: broiler breeder reproduction. In: Nutrition Biotechnology in the feed and food industries. Proceedings of $18^{\text {th }}$ Alltech's Annual Symposium. Ed. T. $P$. Lyon, and $K$. A. Jacques. Nottingham University Press, Nottingham, UK, pp. 29-42.

El-Slamony, A. E., Abdalla, E. A., Faddle, A. A., Mohamed, H. S. and Sabry, M. M. 2015. Effect of supplementing selenium and zinc in diet on some sex hormones, productive, reproductive and physiological parameters of laying Golden Montazah chicken during summer season: 1. The effect on females. Egyptian Poultry Science 35 (111): 647-672.

Glogowski, J., Jankowski, J., Dorota, S., Magdalena, P. and Ciereszko, A. 2004. Quality and biological value of semen collected from turkeytoms fed diets with different zinc content. Archiv fur Geflugelkunde $68(5): 235-238$.

Glogowski, J. Jankowski, J., Faruga, A., Otobre, J. S., Ciereszko, A. 2001. 
Effect of organic selenium and zinc supplementation on fertility and hatchability of turkey eggs

Acrosin activity in turkey spermatozoa: Assay by clinical method and effect of zinc and benzamidine on the activity. Theriogenology 56: 889-901.

Holger, B., Kraus, S., Heindl, P., Bal, W. and Hartwig, A. 2004. Interaction of selenium compounds with zinc finger proteins involved in DNA repair. Eur. J. Biochem., 271: 3190-3199.

Jankowski, J., Suszyn Lska-Rzoska, D., Mro Lz, E., Glogowski, J. and Ciereszko, A. 2001. Effects of level and source of zinc in diet on quality, fertility and hatchability of turkey eggs. Proc. Int. Symp. Ceske Budejovice, p. 45.

Jacob, C., Maret, W. and Vallee, B. L. 1999. Selenium redox biochemistry of zinc-sulfur coordination sites in proteins and enzymes. Proc. Natl. Acad. Sci. USA 96: 1910-1914.

Leeson, S., Namkung, H., Caston, L., Durosoy, S. and Schlegel, $P$. 2008. Comparison of selenium levels and sources and dietary fat quality in diets for broiler breeders and layer hens. Poultry Science 87: 2605-2612.

Ogbu, N. N., Ogbu, C. C. and Ugwu, S. O. C. 2016. Effect of selenium and zinc on biochemical constituents and quality of indigenous turkey semen. International Journal of Agricultural Innovation and Research 4 (5): 865-871.

Ozcelik, M., F. Ekmen, O. EImaz 2009. Effect of location of eggs in the incubator on hatchability of eggs from Bronze turkey breeders of different ages. South African J. Ani. Sci. 39:214-222.
Papazyan, T. T., Lyons, M. P., Mezes, M. and Surai, P. F. 2006. Selenium in poultry nutrition-effects on fertility and hatchability. Praxis Veterinaria 54 (1-2): 85-102.

Siudzinska, A., Lukaszewicz, E. 2008. Effect of semen extenders and storage time on sperm morphology of four chicken breeds. The Journal of Applied Poultry Research 17: $101-108$.

SPSS 2007. Statistical Package for Social Sciences. SPSS Inc. Chicago, USA.

Stanley, V. G., Hitkerson, K., Daley, M. B., Hume, M. and Hinton, A. 2012. Single and combined effects of organic selenium and zinc on egg, fertility, hatchability, and embryonic mortality of exotic Cochin hens. Agrotechnology 2 (1). A v a i l a b l e a t http://dx.doi.org/10.4172/21689881.1000106.

Surai, P., Kostjuk, G., Wishart, A., MacPherson, B. K., Speake, R. C., Ionov, I. N. and Kutz, E. 1998. Effect of vitamin E. and selenium supplementation of cockerel diets on glutathione peroxidase activity and lipid peroxidation susceptibility in sperm, testes, and liver. Biol. Trace Elem. Res. 64: 119-132.
Received: $13^{\text {th }}$ August, 2016 Accepted: $17^{\text {th }}$ March, 2017 